\title{
Effect of $\mathrm{FeO}$ on the formation of spinel phases and chromium distri- bution in the $\mathrm{CaO}-\mathrm{SiO}_{2}-\mathrm{MgO}-\mathrm{Al}_{2} \mathrm{O}_{3}-\mathrm{Cr}_{2} \mathrm{O}_{3}$ system
}

\author{
Jian-li $\mathrm{Li}^{1,2)}$, An-jun $\mathrm{X} \mathrm{u}^{1,2)}$, Dong-feng $\mathrm{H} \mathrm{e}^{1,2)}$, Qi-xing $\mathrm{Yang}^{3)}$, and Nai-yuan Tian ${ }^{1,2)}$ \\ 1) State Key Laboratory of Advanced Metallurgy, University of Science and Technology Beijing, Beijing 100083, China \\ 2) School of Metallurgical and Ecological Engineering, University of Science and Technology Beijing, Beijing 100083, China \\ 3) Division of Sustainable Process Engineering, Luleå University of Technology, Luleå, 97187, Sweden \\ (Received: 12 September 2012; revised: 22 November 2012; accepted: 23 November 2012)
}

\begin{abstract}
Synthetic slag samples of the $\mathrm{CaO}-\mathrm{SiO}_{2}-\mathrm{MgO}-\mathrm{Al}_{2} \mathrm{O}_{3}-\mathrm{Cr}_{2} \mathrm{O}_{3}$ system were obtained to clarify the effect of FeO on the formation of spinel phases and Cr distribution. X-ray diffraction (XRD) and scanning electron microscopy (SEM) equipped with energy-dispersive spectroscopy (EDS), as well as the thermodynamic software FactSage 6.2, were used for sample characterization. The results show that the addition of FeO can decrease the viscosity of molten slag and the precipitation temperatures of melilite and merwinite. The solidus temperature significantly decreases from 1400 to $1250^{\circ} \mathrm{C}$ with the increase of $\mathrm{FeO}$ content from $0 \mathrm{wt} \%$ to $6 \mathrm{wt} \%$. The addition of $\mathrm{FeO}$ could enhance the content of $\mathrm{Cr}$ in spinel phases and reduce the content of $\mathrm{Cr}$ in soluble minerals, such as merwinite, melilite, and dicalcium silicate. Hence, the addition of $\mathrm{FeO}$ is conducive to decreasing Cr leaching.
\end{abstract}

Keywords: stainless steel; slags; spinel phase; chromium; leaching; ferrous oxide

\section{Introduction}

The electric arc furnace (EAF) process is used for melting scraps and alloys to provide molten steel for subsequent refining by argon oxygen decarburization or vacuum oxygen decarburization processes in many stainless steel plants. Chromium (Cr) is an essential alloying element in stainless steel and has a greater affinity with oxygen than iron. An oxygen injection is often practiced in the EAF process to enhance the melting speed and productivity, and also leads to an oxidization of small amount of $\mathrm{Cr}$ [1]. The slag tapped from the EAF process, the EAF slag, contains $\mathrm{Cr}$ oxides of several percent. After leaving the EAF process, the slag is cooled and stored for other utilizations. It has been found by some studies [2-5] that hexavalent $\mathrm{Cr}$ can be generated from $\mathrm{Cr}$ oxides in the EAF slag in the period of slag processing and storage. Hexavalent $\mathrm{Cr}$ is toxic and easily leachable from the slag, leading to water pollution and some economic and ecologic issues. In fear of
Cr leaching, utilizations of EAF slag and other slags from stainless steelmaking are severely circumscribed.

The leachability of Cr mainly depends on the Cr distribution among the minerals existing in the stainless steel slag. Cr could be present in many different mineral phases due to the conditions of nonequilibrium cooling. Numerous mineralogical species present in the slags are soluble in aqueous media, such as merwinite, periclase, dicalcium silicate, and lime, although there are other phases, such as wustite, spinel, and glass, being considered as resistant to water dissolution [6-7]. The investigation of García-Ramos et al. [8] also showed that the Cr leachability has been suppressed by the presence of $\mathrm{MgO}$ or $\mathrm{Al}_{2} \mathrm{O}_{3}$ in the slag system of $\mathrm{CaO}-\mathrm{SiO}_{2}-\mathrm{Cr}_{2} \mathrm{O}_{3}$, with the efficiency of $\mathrm{MgO}$ for the leaching suppression higher than that of $\mathrm{Al}_{2} \mathrm{O}_{3}$, due to the stable binding for $\mathrm{Cr}$ in $\mathrm{MgCr}_{2} \mathrm{O}_{4}$. In addition, the mineralogical and microstructural analyses performed by Tossavainen et al. [9] and Engström et al. [10] have shown that merwinite $\left(\mathrm{Ca}_{3} \mathrm{MgSi}_{2} \mathrm{O}_{8}\right)$, akermanite $\left(\mathrm{Ca}_{2} \mathrm{MgSi}_{2} \mathrm{O}_{7}\right)$,

Corresponding author: An-jun Xu E-mail: anjunxu@126.com

(C) University of Science and Technology Beijing and Springer-Verlag Berlin Heidelberg 2013 
gehlenite $\left(\mathrm{Ca}_{2} \mathrm{Al}_{2} \mathrm{SiO}_{7}\right)$, and spinels were major phases in the EAF slag. Jelkina et al. [11] found that the amount and purity of mineralogical phases present in the synthetic slags of the $\mathrm{CaO}-\mathrm{MgO}-\mathrm{SiO}_{2}-\mathrm{Cr}_{2} \mathrm{O}_{3}-\mathrm{Al}_{2} \mathrm{O}_{3}$ system were highly dependent on the slag composition and heat treatment history.

As one of the components of stainless steel slag, $\mathrm{FeO}$ is an oxidizing agent and a spinel-forming compound and has quite low melting point $\left(1369^{\circ} \mathrm{C}\right)$. Therefore, the change of $\mathrm{FeO}$ content may affect the mineral composition and the distribution of Cr. Researchers from Institut für BaustoffForschung e.V. performed laboratory experiments to decrease the leaching of $\mathrm{Cr}$, and they found that the influence of iron(II) and alumina was most successful [12]. The present experimental work was performed for a better understanding of $\mathrm{FeO}$ effects on the spinel formation and $\mathrm{Cr}$ distribution in EAF slag from stainless steelmaking. Synthetic slag samples of the $\mathrm{CaO}-\mathrm{SiO}_{2}-\mathrm{MgO}-\mathrm{Al}_{2} \mathrm{O}_{3}-\mathrm{Cr}_{2} \mathrm{O}_{3}$ system were prepared for characterization. Thermodynamic calculations were also carried out using FactSage 6.2 to aid discussion on results from the experiments.

\section{Experimental}

Fine powder of reagents, $\mathrm{CaO}, \mathrm{MgO}, \mathrm{Al}_{2} \mathrm{O}_{3}, \mathrm{SiO}_{2}$, and $\mathrm{Cr}_{2} \mathrm{O}_{3}$, of analytical grade were used to prepare synthetic slag samples with the compositions close to the EAF slag generated from stainless steelmaking, as shown in Table 1. The amount of FeO added in samples S1-S3 was 0wt\%, 3wt\%, and $6 \mathrm{wt} \%$, respectively. $\mathrm{CaF}_{2}$ of approximately $3 \mathrm{wt} \%$ was used to decrease the melting point of the slag samples.

Table 1. Compositions of synthetic slag samples of the

\begin{tabular}{cccccccc}
\multicolumn{2}{c}{$\mathbf{C a O}-\mathbf{S i O}_{2}-\mathbf{M g O}-\mathbf{A l}_{2} \mathbf{O}_{3}-\mathbf{C r}_{2} \mathbf{O}_{3}$ system } & & wt\% \\
\hline No. & $\mathrm{CaO}$ & $\mathrm{SiO}_{2}$ & $\mathrm{MgO}$ & $\mathrm{Al}_{2} \mathrm{O}_{3}$ & $\mathrm{Cr}_{2} \mathrm{O}_{3}$ & $\mathrm{FeO}$ & $\mathrm{CaF}_{2}$ \\
\hline $\mathrm{S} 1$ & 45.00 & 32.00 & 8.00 & 6.00 & 6.00 & 0 & 3.00 \\
$\mathrm{~S} 2$ & 43.65 & 31.04 & 7.76 & 5.82 & 5.82 & 3 & 2.91 \\
$\mathrm{~S} 3$ & 42.30 & 30.08 & 7.52 & 5.64 & 5.64 & 6 & 2.82 \\
\hline
\end{tabular}

The reagent powders for each of the slag samples, after thoroughly homogenizing, were placed in an $\mathrm{Al}_{2} \mathrm{O}_{3}$ crucible, which was placed in a graphite crucible inside an induction furnace to heat slowly for sample melting. After the melt temperature reaching $1600^{\circ} \mathrm{C}$, a special procedure of furnace operation was employed to obtain a cooling condition not only for a better crystallization of some slag phases but also for a closer simulation of industry practices for slag cooling. The furnace temperature was measured with an S-type thermocouple. A high-quality argon gas was supplied in the furnace to protect the synthesized slag samples at high temperature. The cooling operation started by first maintaining the melt temperature of $1600^{\circ} \mathrm{C}$ for $30 \mathrm{~min}$ followed by decreasing the temperature to $1450^{\circ} \mathrm{C}$, which was held for $30 \mathrm{~min}$. Then, the temperature declined again and was kept at $1300^{\circ} \mathrm{C}$ for $60 \mathrm{~min}$. After these cooling operations, the slags remained inside the furnace to cool down to room temperature naturally.

The synthetic slag samples were separated from the $\mathrm{Al}_{2} \mathrm{O}_{3}$ crucibles. About $30 \mathrm{~g}$ samples from each of the slags were prepared for characterization. The mineral compositions were determined by powder X-ray diffraction (XRD) analysis (M21x, MAC), with a measuring range of $10^{\circ}-90^{\circ}$ in a step of $0.02^{\circ}$. Microstructural properties of the samples were analyzed using scanning electron microscopy (SEM; Jeol 6480LV) equipped with a Thermo Electron NSS energy-dispersive spectrometer (EDS). Thermodynamic calculations of mineral phases were performed by FactSage 6.2 [13-14]. The compounds of ideal gas and pure solids were included. The databases selected were Fact53, FToxid, FToxid-slagA, FToxid-Mel, and FToxidspinA. Fact53 was suppressed by FToxid to exclude the duplication in the data set. Input data for the slag compositions are from Table 1 . The temperature range was $900-1800^{\circ} \mathrm{C}$ with a step of $10^{\circ} \mathrm{C}$ and the system pressure was set as a constant of $1.013 \times 10^{5} \mathrm{~Pa}$ for the calculations.

\section{Results}

The microstructures of solidified synthetic slags of the $\mathrm{CaO}-\mathrm{SiO}_{2}-\mathrm{MgO}-\mathrm{Al}_{2} \mathrm{O}_{3}-\mathrm{Cr}_{2} \mathrm{O}_{3}$ system with different $\mathrm{FeO}$ contents are shown in Fig. 1. Elemental compositions, based on results from SEM-EDS analysis, of phases identified in Figs. 1(a)-1(c) are presented in Tables 2-4, respectively.

Sample $\mathrm{S} 1$ without $\mathrm{FeO}$ addition consists of four major phases: merwinite $\left(\mathrm{Ca}_{3} \mathrm{MgSi}_{2} \mathrm{O}_{8}\right)$, melilite, $\mathrm{Ca}_{2} \mathrm{SiO}_{4}$ $\left(\mathrm{C}_{2} \mathrm{~S}\right)$, and spinels (Fig. 1(a) and Table 2). Melilite, $\mathrm{C}_{2} \mathrm{~S}$, and spinels are solid solutions. Melilite is formed mainly by akermanite $\left(\mathrm{Ca}_{2} \mathrm{MgSi}_{2} \mathrm{O}_{7}\right)$ and gehlenite $\left(\mathrm{Ca}_{2} \mathrm{Al}_{2} \mathrm{SiO}_{7}\right)$ [15-17]. $\mathrm{MgO}$ may dissolve into the crystal lattice of $\mathrm{Ca}_{2} \mathrm{SiO}_{4}\left(\mathrm{C}_{2} \mathrm{~S}\right)$ through, probably, isomorphous replacement, giving an $\mathrm{Mg}$ content of $3.89 \mathrm{at} \%$ in the phase. The existence of two types of spinels is observed, with phase 4 rich in chromium (Cr 23.27at\%) and phase 5 rich in aluminum (Al 24.02at\%). Data in Table 2 reveal also the $\mathrm{Cr}$ existence in silicates, with merwinite and $\mathrm{C}_{2} \mathrm{~S}$ with a $\mathrm{Cr}$ content of $0.09 \mathrm{at} \%$ and $0.10 \mathrm{at} \%$, respectively.

There are also four mineral phases observed in sample S2 with the FeO content of $3 \mathrm{wt} \%$, similar to the sample without $\mathrm{FeO}$ addition. However, $\mathrm{Cr}$ is measured only in the spinel of phase 9 with the content of 23.09 at\% and the three silicates are free from Cr, as seen in Fig. 1(b) and Table 3. Compared with samples S1 and S2, there are more minerals in sample $\mathrm{S} 3$ with $6 \mathrm{wt} \% \mathrm{FeO}$. The three spinel phases, phases 12-14, are solid solutions with different contents of $\mathrm{Cr}, \mathrm{Al}, \mathrm{Mg}$, and Fe elements, as shown 
in Fig. 1(c) and Table 4. The two silicates and the MeO phase, phases 10,11, and 15, are also Cr free, the same as the three silicates in sample $\mathrm{S} 2$ with the $\mathrm{FeO}$ of $3 \mathrm{wt} \%$.
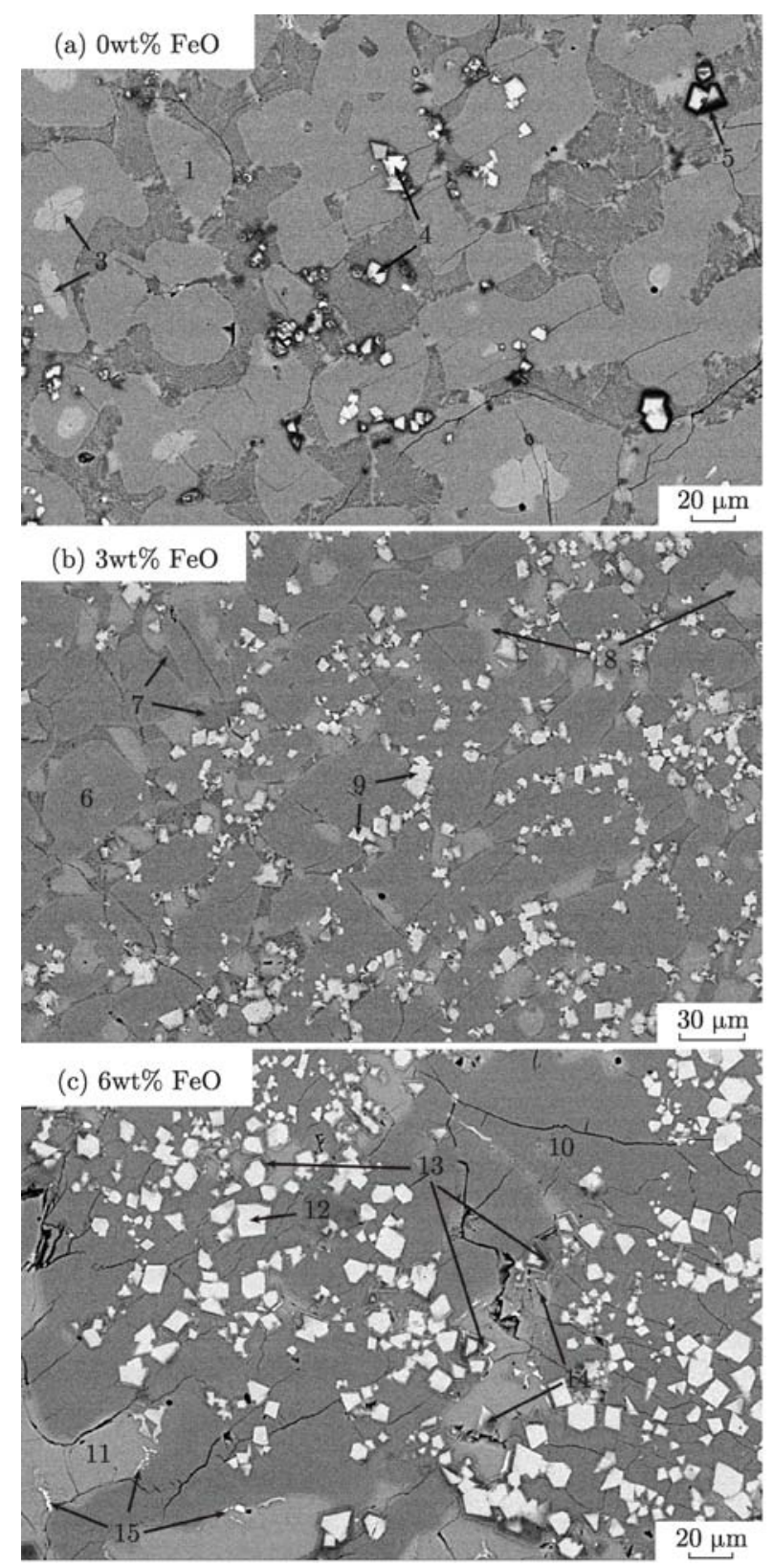

Fig. 1. SEM images of samples S1 (a), S2 (b), and S3 (c).

Table 2. Elemental compositions of mineral phases in sample $\mathrm{S} 1$ shown in Fig. 1(a)

\begin{tabular}{cccrrrrr}
\hline No. & Phase & $\mathrm{O}$ & \multicolumn{1}{c}{$\mathrm{Mg}$} & \multicolumn{1}{c}{$\mathrm{Al}$} & \multicolumn{1}{c}{$\mathrm{Si}$} & \multicolumn{1}{c}{$\mathrm{Ca}$} & \multicolumn{1}{c}{$\mathrm{Cr}$} \\
\hline 1 & Merwinite & 52.22 & 7.84 & 0.42 & 16.66 & 22.77 & 0.09 \\
2 & Melilite & 53.37 & 3.22 & 6.90 & 15.21 & 21.20 & \multicolumn{1}{c}{-} \\
3 & $\mathrm{C}_{2} \mathrm{~S}$ & 52.08 & 3.89 & 1.20 & 16.83 & 25.90 & 0.10 \\
4 & Cr-spinel & 53.12 & 15.71 & 7.15 & 0.26 & 0.49 & 23.27 \\
5 & Al-spinel & 50.95 & 15.31 & 24.02 & 1.32 & 1.13 & 7.27 \\
\hline
\end{tabular}

Table 3. Elemental compositions of mineral phases in sample S2 shown in Fig. 1(b) at\%

\begin{tabular}{ccccrrrrc}
\hline No. & Phase & $\mathrm{O}$ & \multicolumn{1}{c}{$\mathrm{Mg}$} & \multicolumn{1}{c}{$\mathrm{Al}$} & \multicolumn{1}{c}{$\mathrm{Si}$} & $\mathrm{Ca}$ & $\mathrm{Cr}$ & $\mathrm{Fe}$ \\
\hline 6 & Merwinite & 54.16 & 7.30 & 0.47 & 16.26 & 21.64 & - & 0.20 \\
7 & Melilite & 57.19 & 1.54 & 11.14 & 13.87 & 14.72 & - & 1.56 \\
8 & $\mathrm{C}_{2} \mathrm{~S}$ & 53.72 & 0.49 & 0.47 & 16.44 & 28.89 & - & - \\
9 & Spinel & 54.99 & 13.48 & 5.74 & 0.43 & 0.53 & 23.09 & 1.75 \\
\hline
\end{tabular}

Table 4. Elemental compositions of mineral phases in sample S3 shown in Fig. 1(c)

\begin{tabular}{ccccrrrrl}
\hline No. & Phase & $\mathrm{O}$ & \multicolumn{1}{c}{$\mathrm{Mg}$} & \multicolumn{1}{c}{$\mathrm{Al}$} & \multicolumn{1}{c}{$\mathrm{Si}$} & \multicolumn{1}{c}{$\mathrm{Ca}$} & $\mathrm{Cr}$ & $\mathrm{Fe}$ \\
\hline 10 & Merwinite & 52.41 & 7.94 & 0.38 & 16.86 & 22.35 & - & 0.07 \\
11 & $\mathrm{C}_{2} \mathrm{~S}$ & 52.13 & 0.75 & 0.49 & 16.86 & 29.79 & - & - \\
12 & Cr-spinel & 53.64 & 14.56 & 2.74 & 0.15 & 0.38 & 27.21 & 1.32 \\
13 & Al-spinel & 52.85 & 11.02 & 16.61 & 4.84 & 4.83 & 4.37 & 5.48 \\
14 & Spinel & 56.79 & 11.29 & 19.45 & 1.37 & 2.92 & 1.15 & 7.04 \\
15 & MeO* $^{*} 50.60$ & 15.31 & 1.30 & 3.08 & 3.91 & - & 25.75 \\
\hline
\end{tabular}

Note: *Me presents metal elements, such as Mg and Fe.

The contents of $\mathrm{Cr}$ in spinel phases are approximately 23at\% in samples $\mathrm{S} 1$ and $\mathrm{S} 2$, as seen in Tables 2 and 3, respectively. The $\mathrm{Cr}$ content increases to a higher value (27.21at\%; Table 4) in one of the spinel phases (phase 3) in sample $\mathrm{S} 3$ with the $\mathrm{FeO}$ content higher than the two samples. A comparison of slag microstructures in Fig. 1 reveals a clear trend that the amount and size of spinel minerals increase with an increase of $\mathrm{FeO}$ content in the samples.

XRD patterns of the three slag samples are shown in Fig. 2. The peaks of merwinite $\left(\mathrm{Ca}_{3} \mathrm{MgSi}_{2} \mathrm{O}_{8}\right)$ are rather high, indicating that it is a major mineral phase in these samples. Chromite $\left(\mathrm{MgCr}_{2} \mathrm{O}_{4}\right)$ and $\mathrm{MgAl}_{2} \mathrm{O}_{4}$ also appear in all samples. Another spinel mineral, donathite $\left((\mathrm{Fe}, \mathrm{Mg})(\mathrm{Cr}, \mathrm{Fe})_{2} \mathrm{O}_{4}\right)$, is identified in the samples containing $3 \mathrm{wt} \%-6 \mathrm{wt} \%$ FeO.

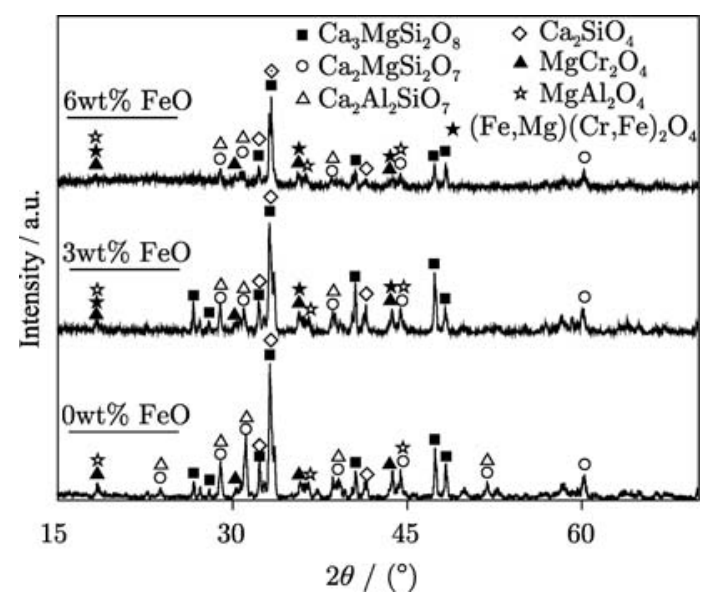

Fig. 2. XRD patterns of slag samples S1, S2, and S3 containing the $\mathrm{FeO}$ contents of $0 \mathrm{wt} \%$, 3wt\%, and $6 \mathrm{wt} \%$, respectively. 
Fig. 3 shows that the mass fractions of merwinite, $\mathrm{Ca}_{3} \mathrm{MgSi}_{2} \mathrm{O}_{8}$, calculated by FactSage 6.2, range from $44 \%$ to $57 \%$ in the three slag samples S1-S3. The calculation indicates also that the mass fractions of spinel minerals are $41.8 \%$ and $70.2 \%$ higher in samples S2 and S3 containing $\mathrm{FeO}$ of $3 \mathrm{wt} \%$ and $6 \mathrm{wt} \%$, respectively, compared with the spinel fraction in sample $\mathrm{S} 1$ without $\mathrm{FeO}$ addition, due to the formation of a new spinel mineral, $\mathrm{FeCr}_{2} \mathrm{O}_{4}$. These calculation results agree rather well with SEM and XRD results in Figs. 1 and 2. Results in Fig. 3 also demonstrate
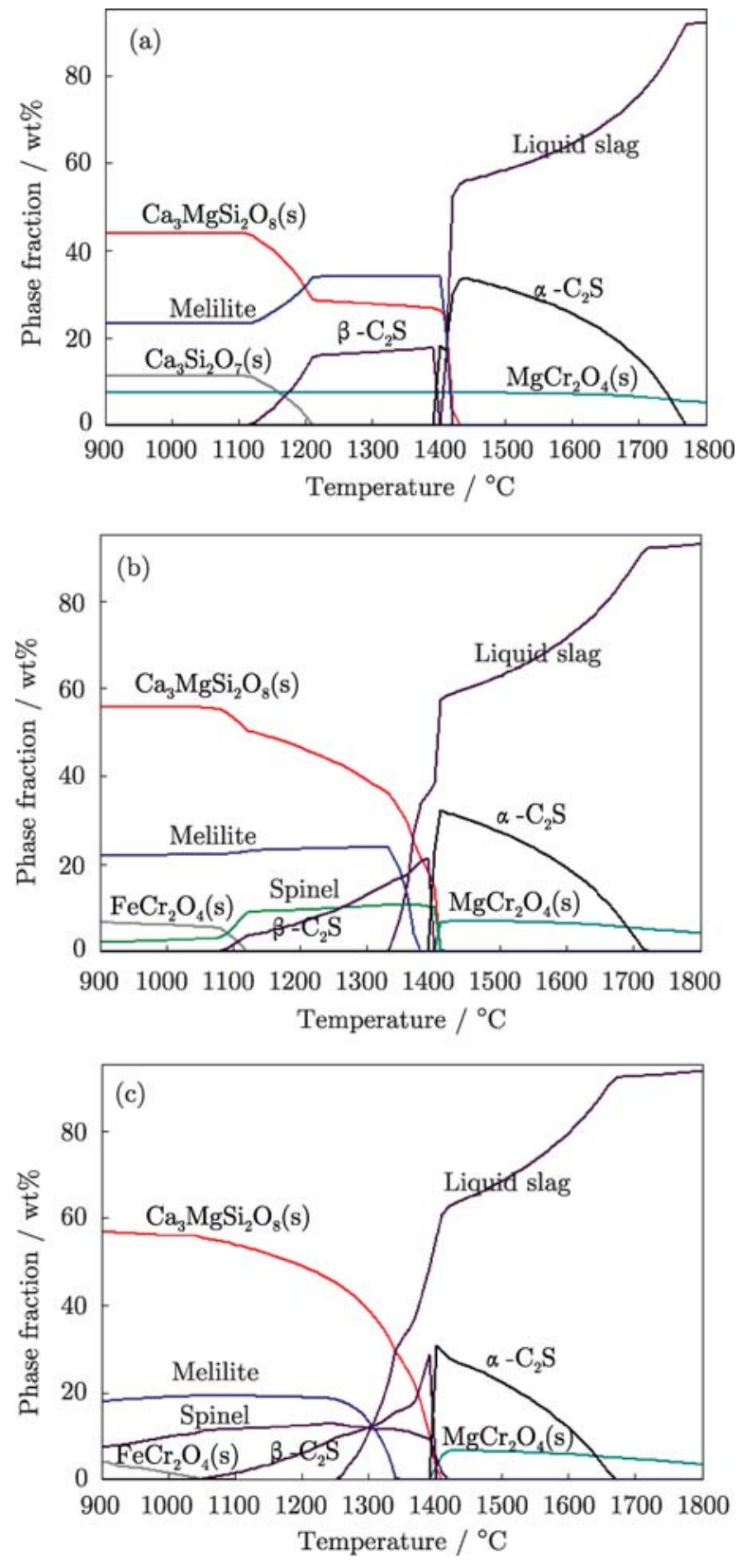

Fig. 3. Mass fractions of mineral phases calculated by FactSage 6.2 for slag samples S1-S3 with the FeO contents of $0 \mathrm{wt} \%, 3 \mathrm{wt} \%$, and $6 \mathrm{wt} \%$, respectively: (a) $\mathrm{S} 1$; (b) S2; (c) S3. that, compared with sample S1, the precipitation temperatures of merwinite and melilite for samples S2 and S3 are lower, as well as the solidus temperature calculated for the two samples.

\section{Discussion}

From the viewpoint of thermodynamics, a solid spinel can be formed via reaction (1) in a simple system of $\mathrm{Mg}$ $\mathrm{Cr}-\mathrm{O}$. With $\mathrm{Al}$ in the system, it is also possible to form the spinel with reaction (2). For a more complicated case, such as adding $\mathrm{FeO}$ in the $\mathrm{Mg}-\mathrm{Cr}-\mathrm{Al}-\mathrm{O}$ system, a reasonable prediction on the formation of spinel minerals may not be straightforward only from thermodynamic considerations.

$$
\begin{aligned}
& \mathrm{MgO}(\mathrm{s})+\mathrm{Cr}_{2} \mathrm{O}_{3}(\mathrm{~s})=\mathrm{MgCr}_{2} \mathrm{O}_{4}(\mathrm{~s}) \\
& \Delta G^{\Theta}=-34462-13.857 T, \mathrm{~J} / \mathrm{mol} . \\
& (\mathrm{MgO})+\left(\mathrm{Cr}_{2} \mathrm{O}_{3}\right)+\left(\mathrm{Al}_{2} \mathrm{O}_{3}\right) \rightarrow \mathrm{Mg}\left(\mathrm{Cr}, \mathrm{Al}_{2} \mathrm{O}_{4}(\mathrm{~s})\right. \\
& (\mathrm{MgO})+(\mathrm{FeO})+\left(\mathrm{Cr}_{2} \mathrm{O}_{3}\right)+\left(\mathrm{Al}_{2} \mathrm{O}_{3}\right) \rightarrow \\
& (\mathrm{Mg}, \mathrm{Fe})(\mathrm{Cr}, \mathrm{Al})_{2} \mathrm{O}_{4}(\mathrm{~s})
\end{aligned}
$$

The concept of isomorphous replacement has been useful for studies in the field of mineralogy. According to this concept, a part of $\mathrm{Mg}^{2+}$ cations can be replaced readily by $\mathrm{Fe}^{2+}$ cations [18], facilitating spinel formation in the $\mathrm{Mg}$ Cr-Al-O system, which can be described using reaction (3). With FeO addition to promote isomorphous replacement, the formation possibility and quantity of the spinel phases may be enhanced.

Additionally, for the growth of spinel crystals in a slag melt, the conditions of mass transfer for oxides in liquid and solid state should be taken into account [19]. It is reasonable to assume the mass transfer depending mainly on diffusion and to use the Fick's first law (Eq. (4)), which specifies that the diffusion flux is a function of diffusion coefficient $D$ and concentration gradient. The concentration gradient is related closely to the slag composition; according to the Stokes-Einstein equation [20] (Eq. (5)), the diffusion coefficient is a function of temperature, ionic radius, and viscosity.

$J_{\mathrm{A}}=-D \frac{\mathrm{d} C_{\mathrm{A}}}{\mathrm{d} x}$

$D=\frac{k_{\mathrm{B}} T}{6 \pi r \eta}$

where $J_{\mathrm{A}}$ is the diffusion flux of component A, $D$ refers to the diffusion coefficient, $C_{\mathrm{A}}$ is the concentration of component $\mathrm{A}, k_{\mathrm{B}}$ is the Boltzman constant, $\eta$ is the viscosity, and $r$ represents the ionic radius.

Results listed in Table 5 show that the viscosity values calculated by FactSage 6.2 for samples $\mathrm{S} 2$ and $\mathrm{S} 3$ with the 
addition of $\mathrm{FeO}$ are lower than the viscosity of sample S1. The results also demonstrate a more pronounced decrease in viscosity at a higher temperature. For instance, the viscosity of sample $\mathrm{S} 1$ (without $\mathrm{FeO}$ ) at $1600^{\circ} \mathrm{C}$ is $0.141 \mathrm{~Pa} \cdot \mathrm{s}$, and that for sample S3 (with 6wt\% FeO) is $0.054 \mathrm{~Pa} \cdot \mathrm{s}$, about one third of that of sample S1.

Table 5. Viscosity $(\eta)$ calculated by FactSage 6.2 for slag melts at different temperatures

\begin{tabular}{ccccc}
\hline \multirow{2}{*}{ Sample } & \multirow{2}{*}{ FeO content / wt\% } & \multicolumn{3}{c}{$\eta /(\mathrm{Pa} \cdot \mathrm{s})$} \\
\cline { 3 - 5 } & & $1600^{\circ} \mathrm{C}$ & $1450^{\circ} \mathrm{C}$ & $1300^{\circ} \mathrm{C}$ \\
\hline S1 & 0 & 0.141 & 0.652 & 1.350 \\
S2 & 3 & 0.098 & 0.596 & 1.273 \\
S3 & 6 & 0.054 & 0.539 & 1.196 \\
\hline
\end{tabular}

Based on the Stokes-Einstein equation (Eq. (5)), with a decrease in viscosity resulting from $\mathrm{FeO}$ addition, the diffusion coefficient $D$ is enhanced [21]. The FeO addition also changes slag composition that leads possibly to an increase in concentration gradient for spinel forming oxides. FeO may then be considered effective for increasing both the diffusion coefficient and the concentration gradient, which, according to the Fick's first law (Eq. (4)), may largely increase the diffusion flux or rate for formation and growth of spinel minerals in the slag system containing $\mathrm{FeO}$.

Besides the decrease of viscosity, for sample S3 (with $6 \mathrm{wt} \% \mathrm{FeO}$ ), the precipitation temperatures of melilite and merwinite and the solidus temperature reduce by 80,30 , and $150^{\circ} \mathrm{C}$, respectively, compared with sample S1 (without $\mathrm{FeO}$ ), referring to temperature data calculated by FactSage 6.2 in Table 6. Based on the temperature decreases, another FeO effect may be deduced regarding the $\mathrm{Cr}$ distribution.

Table 6. Phase precipitation temperatures $\left(T_{\mathbf{P}}\right)$ and solidus temperature $\left(T_{\mathrm{S}}\right)$ calculated by FactSage 6.2

\begin{tabular}{ccccc}
\hline \multirow{2}{*}{ Sample } & \multirow{2}{*}{$\mathrm{FeO}$ Content $/ \mathrm{wt} \%$} & \multicolumn{2}{c}{$T_{\mathrm{P}} /{ }^{\circ} \mathrm{C}$} & \multirow{2}{*}{$T_{\mathrm{S}} /{ }^{\circ} \mathrm{C}$} \\
\cline { 3 - 4 } & & Melilite & Merwinite & \\
\hline $\mathrm{S} 1$ & 0 & 1420 & 1430 & 1400 \\
$\mathrm{~S} 2$ & 3 & 1380 & 1411 & 1330 \\
$\mathrm{~S} 3$ & 6 & 1340 & 1400 & 1250 \\
\hline
\end{tabular}

The decreases in precipitation temperature and solidus temperature due to $\mathrm{FeO}$ addition can contribute to not only an increase of $\mathrm{Cr}$ content in the spinel phase but also a decrease of $\mathrm{Cr}$ content in the soluble minerals. If the temperature for these minerals to form or precipitate and the solidus temperature can be decreased to lower values, there may be more time or a larger chance for some of the Cr remaining in the melt to enter the existing, solid spinel minerals by diffusion at a higher temperature. As a result, since melilite and merwinite start to precipitate at a lower temperature, there may be a very little or no Cr left, consequently making these soluble minerals free of $\mathrm{Cr}$.
For suppressing Cr leaching, it is necessary to minimize a $\mathrm{Cr}$ distribution in the slag minerals, which are easily soluble [11]. It may be difficult to avoid the formation of the minerals, such as melilite and merwinite, in the EAF slag [9-10], but the addition of $\mathrm{FeO}$ reduces the content of $\mathrm{Cr}$ in these minerals. Therefore, $\mathrm{FeO}$ could be considered as an effective additive for a positive $\mathrm{Cr}$ distribution in the slag, by which $\mathrm{Cr}$ is bonded largely in stable spinel minerals and the dissolution of $\mathrm{Cr}$-free silicates does not cause Cr leaching.

The discussion of the present results may imply positive effects of $\mathrm{FeO}$ on the prevention of $\mathrm{Cr}$ leaching from the EAF slag within the $\mathrm{CaO}-\mathrm{SiO}_{2}-\mathrm{MgO}-\mathrm{Al}_{2} \mathrm{O}_{3}-\mathrm{Cr}_{2} \mathrm{O}_{3}$ system. However, any contact of $\mathrm{FeO}$ with the stainless steel melt must be avoided due to the risk of $\mathrm{Cr}$ oxidation by the Fe oxides at high temperature [22].

\section{Conclusions}

The influences of $\mathrm{FeO}$ addition on the formation of spinel phases and $\mathrm{Cr}$ distribution in synthetic slag samples of the $\mathrm{CaO}-\mathrm{SiO}_{2}-\mathrm{MgO}-\mathrm{Al}_{2} \mathrm{O}_{3}-\mathrm{Cr}_{2} \mathrm{O}_{3}$ system were investigated using XRD, SEM-EDS, and thermodynamic software FactSage 6.2. The following results can be obtained.

(1) The amount and size of spinel minerals increase with an increase in $\mathrm{FeO}$ content in the samples. The content of $\mathrm{Cr}$ in the spinel phases are approximately $23 \mathrm{at} \%$ in the samples containing $0 \mathrm{wt} \%-3 \mathrm{wt} \% \mathrm{FeO}$. When the FeO content increases to $6 \mathrm{wt} \%$, the content of $\mathrm{Cr}$ in the spinel phases increases to a higher value (27.21at\%).

(2) $\mathrm{Cr}$ exists in merwinite and $\mathrm{C}_{2} \mathrm{~S}$ with the contents of $0.09 \mathrm{at} \%$ and $0.10 \mathrm{at} \%$, respectively, in the sample without $\mathrm{FeO}$. The silicates become $\mathrm{Cr}$ free with the addition of $3 \mathrm{wt} \%-6 \mathrm{wt} \% \mathrm{FeO}$ in the samples.

(3) The viscosity becomes lower for the samples with an addition of $\mathrm{FeO}$. At $1600^{\circ} \mathrm{C}$, the viscosity for the sample without $\mathrm{FeO}$ is $0.141 \mathrm{~Pa} \cdot \mathrm{s}$ and that for the sample with $6 \mathrm{wt} \% \mathrm{FeO}$ is $0.054 \mathrm{~Pa} \cdot \mathrm{s}$. The $\mathrm{FeO}$ added largely increases the diffusion flux or rate for formation and growth of spinel minerals in the slag samples due to a reduction of viscosity.

(4) For the sample with $6 \mathrm{wt} \% \mathrm{FeO}$, the precipitation temperatures of melilite and merwinite and the solidus temperature decrease by 80,30 , and $150^{\circ} \mathrm{C}$, respectively, compared with the sample without $\mathrm{FeO}$. By decreasing the temperature, the $\mathrm{FeO}$ addition can contribute to not only an increase of $\mathrm{Cr}$ content in the spinel phase but also a decrease of $\mathrm{Cr}$ content in the soluble minerals. This may effectively prevent Cr leaching from the EAF slag.

\section{Acknowledgements}

The authors would like to thank the Chinese Scholar- 
ship Council for financial support and the staff from the Division of Sustainable Process Engineering at Luleå University of Technology for help and assistance.

\section{References}

[1] Y.J. Wu, Z.H. Jiang, L.K. Liang, M.F. Jiang, Z.Z. Huang, and Z.P. Chen, Calculation of some related thermodynamic problems in stainless steel refining process (I): thermodynamics of raw material pretreatment, J. Iron Steel Res., 15(2003), No. 3, p. 1.

[2] Y. Lee and C.L. Nassaralla, Formation of hexavalent chromium by reaction between slag and magnesite-chrome refractory, Metall. Mater. Trans. B, 29(1998), No. 2, p. 405.

[3] Y.M. Lee and C.L. Nassaralla, Standard free energy of formation of calcium chromate, Mater. Sci. Eng. A, 437(2006), No. 2, p. 334.

[4] M. Erdem, H.S. Altundoğan, M.D. Turan, and F. Tümen, Hexavalent chromium removal by ferrochromium slag, $J$. Hazard. Mater., 126(2005), No. 1-3, p. 176.

[5] K.Pillay, H.V. Blottnitz, and J. Petersen, Ageing of chromium(III)-bearing slag and its relation to the atmospheric oxidation of solid chromium(III)-oxide in the presence of calcium oxide, Chemosphere, 52(2003), No. 10, p. 1771.

[6] G.J. Albertsson, Investigations of Stabilization of $\mathrm{Cr}$ in Spinel Phase in Chromium-containing Slags [Dissertation], Royal Institute of Technology, Stockholm, 2011, p. 7.

[7] Y. Samada, T. Miki, and M. Hino, Prevention of chromium elution from stainless steel slag into seawater, ISIJ Int., 51(2011), No. 5, p. 728.

[8] E. García-Ramos, A. Romero-Serrano, B. Zeifert, P. Flores-Sánchez, M. Hallen-López, and E.G. Palacios, Immobilization of chromium in slags using $\mathrm{MgO}$ and $\mathrm{Al}_{2} \mathrm{O}_{3}$, Steel Res. Int., 79(2008), No. 5, p. 332.

[9] M. Tossavainen, F. Engstrom, Q. Yang, N. Menad, M.L. Larsson, and B. Bjorkman, Characteristics of steel slag under different cooling conditions, Waste Manage., 27(2007), No. 10, p. 1335.

[10] F. Engström, D. Adolfsson, Q. Yang, C. Samuelsson, and
B. Björkman, Crystallization behaviour of some steelmaking slags, Steel Res. Int., 81(2010), No. 5, p. 362.

[11] G. Jelkina, L. Teng, B. Bjorkman, and S. Seetharaman, Effect of low oxygen partial pressure on the chromium partition in $\mathrm{CaO}-\mathrm{MgO}-\mathrm{SiO}_{2}-\mathrm{Cr}_{2} \mathrm{O}_{3}-\mathrm{Al}_{2} \mathrm{O}_{3}$ synthetic slag at elevated temperature, [in] 9th International Conference on Molten Slags, Fluxes and Salts, Beijing, 2012, p. 46.

[12] D. Mudersbach, P. Drissen, and H. Motz, Improved slag qualities by liquid slag treatment, [in] 2nd International Slag Valorization Symposium, Leuven, 2011, p. 299.

[13] http://www.factsage.com.

[14] C.W. Bale, P. Chartrand, S.A. Degterov, G. Eriksson, K. Hack, R.B. Mahfoud, J. Melançon, A.D. Pelton, and S. Petersen, FactSage thermochemical software and databases, Calphad, 26(2002), No. 2, p. 189.

[15] C. Fredericci, E.D. Zanotto, and E.C. Ziemath, Crystallization mechanism and properties of a blast furnace slag glass, J. Non Cryst. Solids, 273(2007), No. 1-3, p. 64.

[16] M. Merlini, M. Gemmi, and G. Artioli, Thermal expansion and phase transitions in akermanite and gehlenite, Phys. Chem. Miner., 32(2005), No. 3, p. 189.

[17] I.P. Swainson, M.T. Dove, W.W. Schmahl, and A. Putnis, Neutron powder diffraction study of the akermanitegehlenite solid solution series, Phys. Chem. Miner., 19(1992), p. 185.

[18] L.Q. Zhao, Brief table of isomorphic replacement, Gold Geol., 2(1996), No. 4, p. 39.

[19] Y. Qu, Mass transfer coefficients in metallurgical reactors, J. Univ. Sci. Technol. Beijing, 10(2003), No. 2, p. 1.

[20] T. Gaskell, Self-diffusion in liquid metals: A generalized Stokes-Einstein equation, J. Non Cryst. Solids, 6162(1984), p. 913.

[21] Q.F. Shu and J.Y. Zhang, Viscosity estimation for slags containing calcium fluoride, J. Univ. Sci. Technol. Beijing, 12(2005), No. 3, p. 221.

[22] M. Kuehn and D. Mudersbach, Treatment of liquid EAFslag from stainless steel-making to produce environmental friendly construction materials, [in] SCANMET II-2nd International Conference on Process Development in Iron and Steelmaking, Lulea, 2004, p. 369. 